\title{
DNA methylation landscapes in the pathogenesis of type 2 diabetes mellitus
}

\author{
Zheng Zhou ${ }^{1 \dagger}$, Bao Sun ${ }^{2,3+}$, Xiaoping $\mathrm{Li}^{1}$ and Chunsheng Zhu ${ }^{\text {* }^{*}}$
}

\begin{abstract}
Although genetic variations and environmental factors are vital to the development and progression of type 2 diabetes mellitus (T2DM), emerging literature suggest that epigenetics, especially DNA methylation, play a key role in the pathogenesis of T2DM by affecting insulin secretion of pancreatic $\beta$ cells and the body's resistance to insulin. Previous studies have elucidated how DNA methylation interacted with various factors in T2DM pathogenesis. This review summarized the role of related methylation genes in insulin-sensitive organs, such as pancreatic islets, skeletal muscle, liver, brain and adipose tissue, as well as peripheral blood cells, comparing the tissue similarity and specificity of methylated genes, aiming at a better understanding of the pathogenesis of T2DM and providing new ideas for the personalized treatment of this metabolism-associated disease.
\end{abstract}

Keywords: T2DM, DNA methylation, Insulin secretion, Insulin resistance, Insulin-sensitive organs

\section{Background}

Type 2 diabetes mellitus (T2DM), characterized by a complex, multifactorial, and chronic condition that often necessitates the use of various medications to achieve normal blood glucose, is a complex endocrine and metabolic disorder with dire consequences for human health and well-being. Globally, the estimated prevalence of T2DM is 415 million people in 2015 worldwide, and this figure is projected to rise to 642 million people by 2040 [1]. Significant advances have been made over the past few decades in the understanding of glucose homeostasis and the pathophysiology of T2DM [2]. However, elaborate molecular mechanisms for its pathology remains far from clear.

Increasing evidence showed that the interaction between several genetic and environmental factors contributed to the risk of developing T2DM by causing certain degrees of insulin resistance and pancreatic $\beta$-cell dysfunction [3]. Candidate approaches localized several disease genes, such as transcription factor 7 like 2 (TCF7L2) [4]. Genome-wide association studies and meta-analysis provided new insight into the genetic architecture of T2DM $[5,6]$. However, although over 100 genetic loci had been

\footnotetext{
* Correspondence: zhuchunsheng6@163.com

${ }^{\dagger}$ Zheng Zhou and Bao Sun contributed equally to this work.

${ }^{1}$ Department of Chinese Medicine, The First Affiliated Hospital of Zhengzhou

University, Zhengzhou 450000, China

Full list of author information is available at the end of the article
}

identified, they collectively explained $10 \%$ susceptibility to T2DM, implying other possibilities influencing the nature of disease [7]. Epigenetics, in particular DNA methylation, was also implicated in the pathogenesis of T2DM and other complex metabolism-associated diseases by altering the expression of genes [8-10]. Even more, epigenetics built a molecular link between environmental factors and T2DM [9]. This review focused on DNA methylation landscapes in such insulin-sensitive organs as pancreatic islets, skeletal muscle, liver, kidney, brain and adipose tissue, as well as peripheral blood cells (Table 1).

\section{DNA methylation}

DNA methylation refers to the regulation of gene expression in the presence of impeccable DNA sequences with its patterns set up by DNA methyltransferases (DNMT), including DNMT3A and DNMT3B in early development. More than half of the genes in vertebrate genomes are associated with cytosine-phosphate-guanine $(\mathrm{CpG})$ islands, which is related to the activity of gene transcription [11]. Thus, DNA methylation has been suggested as a natural integrator of genetic susceptibility and environmental exposure in common disease by playing a key role throughout life in tissue specific gene regulation and transcription $[12,13]$. 
Table 1 DNA methylation alterations in T2DM

\begin{tabular}{|c|c|c|c|c|}
\hline $\begin{array}{l}\text { Genes/Susceptibility } \\
\text { factors }\end{array}$ & Methylated status & Insulin-sensitive organs & Effects & References \\
\hline PPARGC1A & Hypermethylation & Human pancreatic islets & Influenced glucose-stimulated insulin secretion & {$[17]$} \\
\hline KCNQ1 & Hypermethylation & Human pancreatic islets & Increased the risk of T2DM & [20] \\
\hline Insulin gene & Demethylation & Human and mouse islet cell & Inhibited the function of beta cell & [21] \\
\hline Insulin gene & Hypermethylation & Human pancreatic islets & Increased the levels of $\mathrm{HbA}_{1 \mathrm{c}}$ & [22] \\
\hline PDX-1 & Hypermethylation & Human pancreatic islets & Associated with the insulin secretion & [23] \\
\hline GLP1R & Hypermethylation & Human pancreatic islets & Positively associated with $\mathrm{BMI}$ and $\mathrm{HbA}_{1 \mathrm{c}}$ & [24] \\
\hline MEG3-DLK1 microRNA & Hypermethylation & Human pancreatic islets & Caused the increase of $\beta$ cell apoptosis & [25] \\
\hline Ageing & Hypermethylation & Rat pancreatic islets & Associated with molecular inflammation & [26] \\
\hline NDUFB6 & Hypermethylation & Human skeletal muscle & Influenced insulin sensitivity & [35] \\
\hline cox5a & Hypermethylation & Rat skeletal muscle & Associated with mitochondrial dysfunction & {$[36]$} \\
\hline COX7A1 & Hypermethylation & Human skeletal muscle & Associated with glucose uptake in vivo & [37] \\
\hline Gastric bypass surgery & Hypomethylation & Human skeletal muscle & $\begin{array}{l}\text { Remodeled the promoter methylation } \\
\text { of PGC-1a and PDK4 }\end{array}$ & {$[38]$} \\
\hline Acute exercise & Hypomethylation & Human skeletal muscle & Activated contraction-induced gene & [39] \\
\hline lonizing radiation & Hypermethylation & Mice skeletal muscle cells & Increased the risk of insulin resistance & {$[40]$} \\
\hline $\begin{array}{l}\text { Insulin and glucose } \\
\text { exposure }\end{array}$ & $\begin{array}{l}\text { Hypermethylation } \\
\text { and hypomethylation }\end{array}$ & Human skeletal muscle & Altered the DAPK3 methylation & [41] \\
\hline Gck & Hypermethylation & Rat liver & Involved in the development of insulin resistance & {$[42,43]$} \\
\hline TNFa & Hypermethylation & Mice liver and adipose tissue & Associated with the reduction of inflammation & [44] \\
\hline $\begin{array}{l}\text { Metformin transporter } \\
\text { genes }\end{array}$ & Demethylation & Human liver & Improved hyperglycaemia and obesity & [45] \\
\hline In-utero malnutrition & Hypermethylation & Mice liver & Influenced the expression of lipogenic genes & {$[46]$} \\
\hline Loss of MBD2 & Hypermethylation & Mice liver & Protected mice from insulin resistance & {$[52]$} \\
\hline IGFBP1 and IGFBP7 & Hypermethylation & Human peripheral blood & Associated with insulin resistance & {$[53,54]$} \\
\hline Alu repeats & Hypermethylation & $\begin{array}{l}\text { Human peripheral blood } \\
\text { leukocytes }\end{array}$ & Associated with insulin resistance & [59] \\
\hline LINE-1 & Hypomethylation & Human peripheral blood & Increased the risk of metabolic worsening & {$[60]$} \\
\hline MCP-1 & Hypomethylation & Human peripheral blood & Increased the serum MCP-1 level & [61] \\
\hline TCF7L2 & Hypermethylation & Human peripheral blood & Positively associated with fasting glucose & {$[62]$} \\
\hline TXNIP & Hypomethylation & Human peripheral blood & Increased $\mathrm{HbA}_{1 \mathrm{c}}$ and fasting glucose & {$[65]$} \\
\hline NR4A1 & Hypomethylation & Human peripheral blood & Decreased the blood glucose & {$[66]$} \\
\hline Aging & Hypermethylation & Human brain and blood & Remodeled DNA methylation & [67] \\
\hline
\end{tabular}

Intriguingly, DNA methylation was found more abundant in gene bodies and often positively correlated with gene expression in recent years [14]. Besides, Aran et al. discovered that DNA methylation of enhancers could regulate transcription levels of distal promoters through binding of transcription factors and chromatin modulating proteins [15]. Additionally, genome-wide studies of the methylome had identified that the position of the methylation in the transcriptional site influenced its relationship to gene control. As a result, in the growing incidence of T2DM, DNA methylation alterations might be involved in its pathogenesis by affecting insulin secretion of pancreatic $\beta$ cells and the body's resistance to insulin across multiple tissues (Fig. 1).

\section{DNA methylation and T2DM}

DNA methylation alterations in pancreatic islets of T2DM

Pancreatic islets, mainly secreting insulin and glucagon, is composed of a group of hormone-secreting cells. Among them, pancreatic $\beta$ cells are of utmost importance to regulate glycemia during the development of T2DM. Hence, it is essential to know mechanisms that affect the function of $\beta$ cells in depth for finding new treatment options for T2DM.

Peroxisome proliferative activated receptor gamma coactivator 1 alpha (PPARGC1A), a transcriptional co-activator encoding PGC1 $\alpha$, was aberrantly expressed and related to impaired oxidative phosphorylation in skeletal muscle from patients with T2DM [16]. However, 


\section{Epigenetic factors}

Age, obesity, environmental factors, high-fat diet, exercise, palmitate, et al.

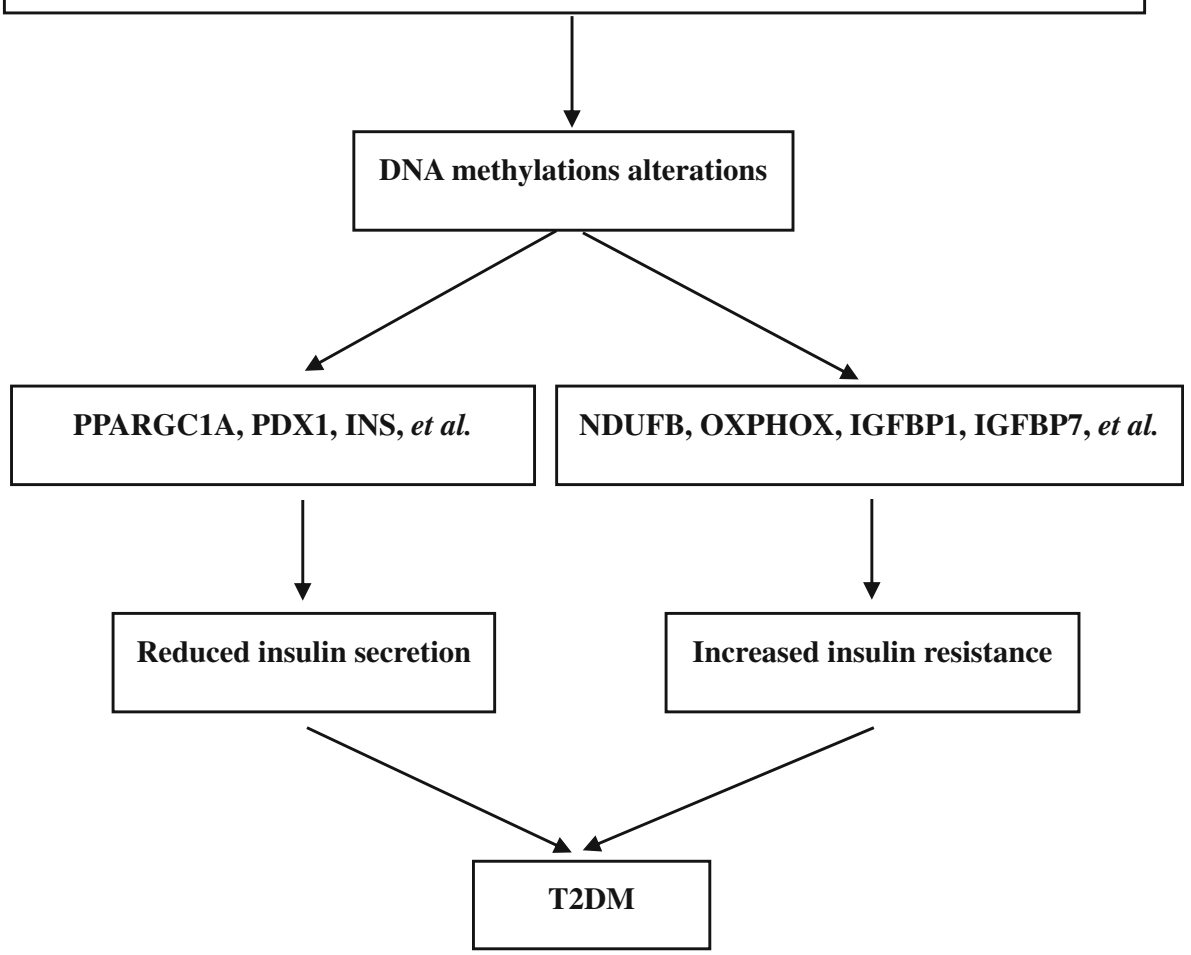

Fig. 1 DNA methylation alterations affected insulin secretion and insulin resistance in the development of T2DM

increased levels of methylation of the PPARGC1A gene promoter were similarly associated with its reduced expression in human pancreatic islets from T2DM patients, influencing glucose-stimulated insulin secretion [17]. The T2DM risk gene potassium voltage-gated channel subfamily Q member 1 (KCNQ1) was identified to be associated with impaired islet function [18, 19]. Travers et al. suggested that hypermethylation of the imprinted 11p15.5 region of KCNQ1 might be mediated by its genetic risk variants in both fetal pancreas and adult human islets tissues [20]. As a master regulator of metabolic homeostasis, insulin gene might be regulated by DNA methylation [21]. Yang et al. demonstrated that hypermethylation of the insulin promoter in pancreatic islets from T2DM patients was correlated negatively with insulin gene expression and positively with glycosylated hemoglobin $\left(\mathrm{HbA}_{1 \mathrm{c}}\right)$ levels [22]. Pancreatic duodenal homeobox 1 (PDX-1) was a transcription factor that exhibited decreased expression in human pancreatic islets and was associated with insulin secretion, which was significantly associated with the hypermethylation of its promoter and enhancer regions [23]. Glucagon-like peptide 1 (GLP-1), an incretin hormone, enhanced insulin secretion by binding to its receptor (GLP1R) in pancreatic $\beta$ cells. Hall et al. showed that hypermethylation of GLP1R in human pancreatic islets had positive correlation with body mass index (BMI) and $\mathrm{HbA}_{1 \mathrm{c}}$ of T2DM patients [24]. Moreover, another high-throughput study by Kameswaran et al. supported that MEG-DLK1 microRNA cluster was highly expressed in $\beta$ cells, but repressed in human islets from T2DM donors, which was identified to be regulated by epigenetic modification [25]. Recently, Sandovici et al. suggested that age-associated transcriptional differences were negatively correlated with the methylation of several inflammation-related gene promoters in rat pancreatic islets, shedding a new light on epigenetic signatures in islets [26]. Moreover, perturbations in the intrauterine environment increasing the susceptibility of age-related diseases induced alterations in DNA methylation and gene expression in pancreatic islets of rats [27]. Meaningfully, the phenotype of T2DM was found to be potentially affected by 19 diabetes-associated single-nucleotide polymorphisms (SNPs) on which a CpG site was introduced or removed using pancreatic islets from T2DM donors, establishing the relationship between genetic variation and epigenetics [28]. 
With the development of high throughput sequencing, DNA methylation profiling was performed in pancreatic islets from T2DM patients. Volkmar et al. uncovered 276 CpG loci displaying differential DNA methylation by performing comprehensive DNA methylation profiling in human pancreatic islets [29]. Another genome-wide DNA methylation analysis identified $1649 \mathrm{CpG}$ sites and 853 genes with differential DNA methylation in human islets. Further functional analyses found several new methylated target genes with altered expression that contributed to impaired insulin and glucagon secretion [30]. Olsson et al. demonstrated that genome-wide genetic and epigenetic variation interacted to influence gene expression in human islets [31]. Recently, whole-genome bisulfite sequencing by Volkov et al. provided a picture of DNA methylome in human pancreatic islets and stressed the importance of epigenetic changes in the pathogenesis of T2DM [32]. Interestingly, palmitate treatment of human pancreatic islets gave rise to DNA methylation modifications, which might cause impaired insulin secretion and aggravated T2DM [33]. Lately, aging increased DNA methylation of 241 sites that were identified in human islets and associated with insulin secretion [34].

\section{DNA methylation modifications in skeletal muscle}

As an important insulin-sensitive organ, skeletal muscle was the main tissue responsible for glucose uptake. DNA methylation modifications in skeletal muscle might contribute to insulin resistance, which was beneficial for understanding the pathogenesis of T2DM.

Studies found that increased DNA methylation in the promoter of ubiquinone oxidoreductase subunit B6 (NDUFB6) was correlated negatively with its expression in skeletal muscle from T2DM patients, which subsequently influenced insulin sensitivity [35]. Gong et al. observed that hypermethylation of cytochrome c oxidase $5 \mathrm{a}(\mathrm{COX} 5 \mathrm{a})$ was related with mitochondrial dysfunction in skeletal muscle of high-fat diet (HFD) induced rats [36]. Furthermore, Rönn et al. provided evidence that age was a factor influencing DNA methylation of COX7A1 that encoded oxidative phosphorylation (OXPHOS) gene in human skeletal muscle [37]. They found that the methylation of the COX7A1 promoter was increased in muscle from elderly compared with young twins. Besides, Roux-en-Y gastric bypass could remodel the promoter methylation of genes in skeletal muscle. Barres et al. revealed that the methylation of PGC-1 $\alpha$ and pyruvate dehydrogenase kinase 4 (PDK4) was reduced with obesity and restored to nonobese levels after Roux-en-Y gastric bypass [38]. Analogously, acute exercise also could decrease promoter methylation and trigger structural and metabolic adaptations in skeletal muscle [39]. Whole genome methylation study indicated that the promoter methylation of PGC- $1 \alpha$, PDK4 and PPAR- $\delta$ was dramatically decreased in mouse soleus muscles [39]. Recently, Nylander et al. revealed that ionizing radiation altered substantial DNA methylation in skeletal muscle and adipose progenitor cells, increasing the risk of insulin resistance and T2DM [40]. Additionally, insulin and glucose exposure altered the DNA methylation profile and modulated death-associated protein kinase 3 (DAPK3) DNA methylation in skeletal muscle from T2DM patients [41].

\section{DNA methylation changes in liver and adipose tissue}

Liver and adipose tissue were essential for maintaining the balance of glucose homeostasis, being the important endocrine system affecting many metabolic pathways.

Earlier study by Jiang et al. demonstrated that hypermethylation of hepatic glucokinase (Gck) contributed to diabetogenic potential in the liver from aging rats [42]. They also indicated that hypermethylation level of Gck and L-type pyruvate kinase (LPK) promoters was involved in the development of insulin resistance in high-fat diet-induced obese rats [43]. Of note, helichrysum and grapefruit extracts increased DNA methylation of TNF $\alpha$ in the liver and adipose tissue from diabetic mice, which might be associated with the reduction of inflammation in diabetes and obesity [44]. Metformin decreased DNA methylation of metformin transporter genes in the human liver, which might be conducive to improving hyperglycaemia and obesity [45]. Besides, in-utero malnutrition resulted in DNA methylation modifications in germ cells, which subsequently influenced the expression of lipogenic genes in livers of offspring mice [46]. Of late years, genome-wide methylome and transcriptome analysis highlighted that epigenetic and transcriptional changes in the liver from patients with T2DM played an important role in its etiology [47, 48]. In addition to that, subjects with T2DM also exhibited transcriptional and epigenetic changes in adipose tissue relevant to the development of the disease [49]. By using the Infinium HumanMethylation450 BeadChip assay, Rönn et al. stressed that increased age, $\mathrm{BMI}$ and $\mathrm{HbA}_{1 \mathrm{c}}$ levels had a great influence on epigenetic variation of candidate genes of T2DM in human adipose tissue [50]. Another genome-wide DNA methylation research revealed that patients were predisposed to insulin resistance and T2DM with aberrant DNA methylation in the visceral adipose tissue [51]. Recently, study by Cheng et al. discovered that loss of methyl-CpG-binding domain 2 (MBD2) resulted in DNA methylation changes associated with altered energy homeostasis, which protected mice from HFD-induced obesity and insulin resistance [52].

\section{DNA methylation shifts in peripheral blood cells}

Although DNA methylation in tissues had been widely studied, it was difficult for some human tissues such as 
pancreatic islets, liver, skeletal muscle and adipose tissue to be non-invasively assessed. Thus, blood might be considered as a fitting surrogate marker for reflecting DNA methylation in tissues. Gu et al. demonstrated that the methylation levels of insulin-like growth factor-binding protein 1 (IGFBP1) and IGFBP7 were increased in peripheral blood from Swedish men with newly diagnosed T2DM [53, 54]. Genome-wide survey uncovered that low methylation level in human peripheral blood was an early marker of T2DM [55]. Specifically, global DNA methylation analysis unraveled that methylation level was increased in B cells and natural killer cells, but unchanged in monocytes, lymphocytes or $\mathrm{T}$ cells from obese and T2DM patients [56]. del Rosario et al. also supported that DNA methylation shifts in peripheral blood leukocytes of mothers who had diabetes during pregnancy were associated with increased risk for T2DM of their offspring [57]. Beyond that, premature DNA methylation aging in peripheral blood leukocytes was also correlated with increased risk of T2DM [58]. A monozygotic twin study showed that insulin resistance was probably associated with global DNA methylation of Alu repeats in peripheral blood leukocytes [59]. In addition, a cohort study suggested that hypomethylation of long interspersed nucleotide element 1 (LINE-1) in peripheral blood was correlated with a higher risk metabolic status worsening [60]. Like some T2DM-associated susceptibility gene methylated in tissues, several risk genes also exhibited methylation changes in peripheral blood from T2DM patients [61, 62]. Hypomethylation of monocyte chemoattractant protein-1 (MCP-1) promoter region in the peripheral blood mononuclear cells (PBMC) was correlated to the serum MCP-1 level, $\mathrm{HbA}_{1 \mathrm{c}}$ and fasting blood glucose in T2DM patients [61]. Moreover, abnormal methylation of TCF7L2 promoter was further related to fasting glucose in peripheral blood from T2DM patients [62]. Epigenome-wide association study found five methylation markers that were associated with future T2DM incidence, including ATP binding cassette subfamily G member 1 (ABCG1), phosphocholine phosphatase (PHOSPHO1), suppressor of cytokine signaling 3 (SOCS3), sterol regulatory element binding transcription factor 1 (SREBF1) and thioredoxin interacting protein (TXNIP), throwing new lights on the pathogenesis underlying T2DM [63]. Subsequently, Dayeh et al. validated the five genes in blood DNA of subjects from the prospective study, but only found the association of ABCG1 and PHOSPHO1 methylation with the risk of T2DM [64]. Furthermore, Florath et al. investigated that decreased methylation levels at cg19693031 located in the 3'-untranslated regions of TXNIP might increase fasting glucose and $\mathrm{HbA}_{1 \mathrm{c}}$ concentrations in T2DM patients [65]. Recently, Chen et al. showed that reversing the methylation of the nuclear receptor subfamily 4 group A member 1 (NR4A1) contributed to its high expression and decreased blood glucose in T2DM patients [66].

In addition to the above insulin-sensitive organs or tissues, recent study reported aging effects on DNA methylation modules in human brain and blood tissue, which signified that DNA methylation shifts might also exist in brain or other specific tissues from T2DM patients [67]. Also, the desensitization of insulin receptors in the brain might be regulated by epigenetic mechanisms that played a pivotal role in the pathogenesis of both Alzheimer's disease and T2DM [68].

\section{Conclusion and future perspective}

Novel research in the field of epigenetics opened up new sights into the pathogenesis of T2DM and provided further opportunities of identifying biomarkers for this complex metabolic disease. Epigenome-wide as well as site specific DNA methylation association studies were rapidly revealing different methylated genes in insulin-sensitive organs or tissues from T2DM patients. Even more, some certain methylation sites were introduced or removed by the mutation of T2DM susceptibility genes, partially elucidating the molecular mechanisms through which the T2DM SNPs affected gene function via differential DNA methylation [28]. In the last year, mechanistic studies of DNA methylation regulation indicated the correlation between cellular signaling pathways and DNA methylation [69], thereby increasing the possibilities to understand the etiology of T2DM and leading to a personal treatment for this disordered disease.

Current data supported the view that DNA methylation changes in different relevant metabolic tissues such as pancreatic islets, skeletal muscle, liver, brain, adipose tissue and PBMCs might be involved in the pathogenesis of T2DM. It was interesting to find that DNA methylation modifications in several certain genes were common within human tissues [70, 71]. Hence, DNA methylation in blood, a potential surrogate for other hard-to-get tissues, might be promising biomarkers for T2DM. Lifestyle changes might modify DNA methylation and thus gene expression during the development of T2DM. Targeted researches brought us closer to a better understanding of the epigenetic signatures that were associated with either age- or lifestyle-related phenotypes, which might be helpful for identifying new therapeutic targets for improving insulin sensitivity $[67,72,73]$.

As a common complex metabolic disorder, the detailed mechanisms of T2DM remained obscure. Day et al. proposed that a simple epigenetic drift model was insufficient to explain age-dependent methylation in tissues from T2DM patients [70]. Genetic and epigenetic study, recently reviewed by Kwak and his colleague, 
discussed how genetic, environmental factors and epigenetics interacted in the pathogenesis of T2DM [74]. Even more, an integrated T2DM knowledgebase that could access aggregated large-scale genetic data was appealed for advancing complex disease research [75]. Given this, large-scale epigenetic information was also required to form a database to facilitate our understanding of T2DM biology and improve patient treatment and outcomes.

In conclusion, DNA methylation provides an efficient tool for the recognition and interpretation of T2DM. Taking the role of DNA methylation in the pathogenesis of T2DM into account may contribute to a more personalized application of therapy for metabolic diseases in the future.

\begin{abstract}
Abbreviations
ABCG1: ATP binding cassette subfamily G member 1; BMI: Body mass index; COX5a: Cytochrome c oxidase 5a; CpG: Cytosine-phosphate-guanine; DAPK3: Death-associated protein kinase 3; DNMT: DNA methyltransferases; Gck: Glucokinase; GLP-1: Glucagon-like peptide 1; $\mathrm{HbA}_{1 c}$ : Glycosylated hemoglobin; HFD: High-fat diet; IGFBP1: Insulin-like growth factor-binding protein 1; KCNQ1: Potassium voltage-gated channel subfamily $\mathrm{Q}$ member 1; LINE-1: Long interspersed nucleotide element 1; LPK: L-type pyruvate kinase; MBD2: Methyl-CpG-binding domain 2; MCP-1: Monocyte chemoattractant protein-1; NDUFB6: Ubiquinone oxidoreductase subunit B6; NR4A1: Nuclear receptor subfamily 4 group A member 1; OXPHOS: Oxidative phosphorylation; PBMC: Peripheral blood mononuclear cells; PDK4: Pyruvate dehydrogenase kinase 4; PDX-1: Pancreatic duodenal homeobox 1; PHOSPHO1: Phosphocholine phosphatase: PPARGC1A: Peroxisome proliferative activated receptor gamma coactivator 1 alpha; SNPs: Singlenucleotide polymorphisms; SOCS3: Suppressor of cytokine signaling 3; SREBF1: Sterol regulatory element binding transcription factor 1; T2DM: Type 2 diabetes mellitus; TCF7L2: Transcription factor 7 like 2; TXNIP: Thioredoxin interacting protein
\end{abstract}

\section{Acknowledgments}

The authors wish to acknowledge Xiaochuan Zhang from the First Affiliated Hospital of Zhengzhou University, China for editing of English grammar and syntax of the manuscript.

\section{Authors' contributions}

ZZ, BS and CSZ contributed towards the concept and manuscript writing; XPL revised and supervised overall project. All authors read and approved the final version of manuscript.

\section{Ethics approval and consent to participate}

Not applicable.

\section{Consent for publication}

Each author meets the criteria for authorship and assumes the corresponding responsibility.

\section{Competing interests}

The authors declare that they have no competing interests.

\section{Publisher's Note}

Springer Nature remains neutral with regard to jurisdictional claims in published maps and institutional affiliations.

\section{Author details}

'Department of Chinese Medicine, The First Affiliated Hospital of Zhengzhou University, Zhengzhou 450000, China. ${ }^{2}$ Department of Clinical Pharmacology, Xiangya Hospital, Central South University, Changsha 410000, China. ${ }^{3}$ Hunan Key Laboratory of Pharmacogenetics, Institute of Clinical Pharmacology, Central South University, Changsha 410000, China.
Received: 23 April 2018 Accepted: 18 June 2018

Published online: 28 June 2018

\section{References}

1. International Diabetes Federation, Global burden. Sixth edition. 2014. http://www.idf.org/diabetesatlas/5e/the-global-burden; Accessed 9 February 2015.

2. Kahn SE, Cooper ME, Del Prato S. Pathophysiology and treatment of type 2 diabetes: perspectives on the past, present, and future. Lancet. 2014; 383(9922):1068-83.

3. Stumvoll M, Goldstein BJ, van Haeften TW. Type 2 diabetes: principles of pathogenesis and therapy. Lancet. 2005;365(9467):1333-46.

4. Grant SF, Thorleifsson G, Reynisdottir I, Benediktsson R, Manolescu A, Sainz J, et al. Variant of transcription factor 7-like 2 (TCF7L2) gene confers risk of type 2 diabetes. Nat Genet. 2006;38(3):320-3.

5. Mahajan A, Go MJ, Zhang W, Below JE, Gaulton KJ, Ferreira T, et al. Genome-wide trans-ancestry meta-analysis provides insight into the genetic architecture of type 2 diabetes susceptibility. Nat Genet. 2014;46(3):234-44.

6. Morris AP, Voight BF, Teslovich TM, Ferreira T, Segre AV, Steinthorsdottir V, et al. Large-scale association analysis provides insights into the genetic architecture and pathophysiology of type 2 diabetes. Nat Genet. 2012;44(9):981-90.

7. McCarthy MI. Genomic medicine at the heart of diabetes management. Diabetologia. 2015;58(8):1725-9.

8. Barres R, Zierath JR. DNA methylation in metabolic disorders. Am J Clin Nutr. 2011;93(4):897s-00

9. $\quad$ Ling C, Groop L. Epigenetics: a molecular link between environmental factors and type 2 diabetes. Diabetes. 2009;58(12):2718-25.

10. Ling C, Ronn T. Epigenetic markers to further understand insulin resistance. Diabetologia. 2016;59(11):2295-7.

11. Antequera F, Bird A. Number of $\mathrm{CpG}$ islands and genes in human and mouse. Proc Nati Acad Sci U S A. 1993;90(24):11995-9.

12. Bjornsson HT, Fallin MD, Feinberg AP. An integrated epigenetic and genetic approach to common human disease. Trends Genet. 2004;20(8):350-8.

13. Jones PA. Functions of DNA methylation: islands, start sites, gene bodies and beyond. Nat Rev Genet. 2012;13(7):484-92.

14. Lev Maor G, Yearim A, Ast G. The alternative role of DNA methylation in splicing regulation. Trends Genet. 2015;31(5):274-80.

15. Aran D, Sabato S, Hellman A. DNA methylation of distal regulatory sites characterizes dysregulation of cancer genes. Genome Biol. 2013;14(3):R21.

16. Mootha VK, Lindgren CM, Eriksson KF, Subramanian A, Sihag S, Lehar J, et al. PGC1-alpha-responsive genes involved in oxidative phosphorylation are coordinately downregulated in human diabetes. Nat Genet. 2003;34(3):267-73.

17. Ling C, Del Guerra S, Lupi R, Ronn T, Granhall C, Luthman H, et al. Epigenetic regulation of PPARGC1A in human type 2 diabetic islets and effect on insulin secretion. Diabetologia. 2008:51(4):615-22.

18. Jonsson A, Isomaa B, Tuomi T, Taneera J, Salehi A, Nilsson P, et al. A variant in the KCNQ1 gene preicts future type 2 diabetes and mediates impaired insulin secretion. Diabetes. 2009:58(10):2409-13.

19. Tan JT, Nurbaya S, Gardner D, Ye S, Tai ES, Ng Daniel PK. Genetic variation in KCNQ1 associates with fasting glucose and beta-cell function: a study of 3734 subjects comprising three ethnicities living in Singapore. Diabetes. 2009:58(6):1445-9.

20. Travers ME, Mackay DJ, Dekker NM, Morris AP, Lindgren CM, Berry A, et al. Insights into the molecular mechanism for type 2 diabetes susceptibility at the KCNQ1 locus from temporal changes in imprinting status in human islets. Diabetes. 2013;62(3):987-92.

21. Kuroda A, Rauch TA, Todorov I, Ku HT, Al-Abdullah IH, Kandeel F, et al. Insulin gene expression is regulated by DNA methylation. PLoS One. 2009; 4(9):e6953.

22. Yang BT, Dayeh TA, Kirkpatrick CL, Taneera J, Kumar R, Groop L, et al. Insulin promoter DNA methylation correlates negatively with insulin gene expression and positively with $\mathrm{HbA}(1 \mathrm{c})$ levels in human pancreatic islets. Diabetologia. 2011;54(2):360-7.

23. Yang BT, Dayeh TA, Volkov PA, Kirkpatrick CL, Malmgren S, Jing X, et al. Increased DNA methylation and decreased expression of PDX-1 in pancreatic islets from patients with type 2 diabetes. Mol Endocrinol. 2012; 26(7):1203-12

24. Hall E, Dayeh T, Kirkpatrick CL, Wollheim CB, Nitert MD, Ling C. DNA methylation of the glucagon-like peptide 1 receptor (GLP1R) in human pancreatic islets. BMC Med Genet. 2013;14:76. 
25. Kameswaran V, Bramswig NC, McKenna LB, Penn M, Schug J, Hand NJ, et al. Epigenetic regulation of the DLK1-MEG3 microRNA cluster in human type 2 diabetic islets. Cell Metab. 2014;19(1):135-45.

26. Sandovici I, Hammerle CM, Cooper WN, Smith NH, Tarry-Adkins JL, Dunmore BJ, et al. Ageing is associated with molecular signatures of inflammation and type 2 diabetes in rat pancreatic islets. Diabetologia. 2016;59(3):502-11.

27. Thompson RF, Fazzari MJ, Niu H, Barzilai N, Simmons RA, Greally JM. Experimental intrauterine growth restriction induces alterations in DNA methylation and gene expression in pancreatic islets of rats. J Biol Chem. 2010;285(20):15111-8.

28. Dayeh TA, Olsson AH, Volkov P, Almgren P, Ronn T, Ling C. Identification of CpG-SNPs associated with type 2 diabetes and differential DNA methylation in human pancreatic islets. Diabetologia. 2013;56(5):1036-46.

29. Volkmar M, Dedeurwaerder S, Cunha DA, Ndlovu MN, Defrance M, Deplus R et al. DNA methylation profiling identifies epigenetic dysregulation in pancreatic islets from type 2 diabetic patients. EMBO J. 2012;31(6):1405-26.

30. Dayeh T, Volkov P, Salo S, Hall E, Nilsson E, Olsson AH, et al. Genome-wide DNA methylation analysis of human pancreatic islets from type 2 diabetic and non-diabetic donors identifies candidate genes that influence insulin secretion. PLoS Genet. 2014;10(3):e1004160.

31. Olsson AH, Volkov P, Bacos K, Dayeh T, Hall E, Nilsson EA, et al. Genomewide associations between genetic and epigenetic variation influence mRNA expression and insulin secretion in human pancreatic islets. PLoS Genet. 2014;10(11):e1004735

32. Volkov P, Bacos K, Ofori JK, Esguerra JL, Eliasson L, Ronn T, et al. Wholegenome bisulfite sequencing of human pancreatic islets reveals novels differentially methylated regions in type 2 diabetes pathogenesis. Diabetes. 2017;66(4):1074-85.

33. Hall E, Volkov P, Dayeh T, Bacos K, Ronn T, Nitert MD, et al. Effects of palmitate on genome-wide mRNA expression and DNA methylation patterns in human pancreatic islets. BMC Med. 2014;12:103.

34. Bacos K, Gillberg L, Volkov P, Olsson AH, Hansen T, Pedersen O, et al. Bloodbased biomarkers of age-associated epigenetic changes in human islets associate with insulin secretion and diabetes. Nat Commun. 2016;7:11089.

35. Ling C, Poulsen P, Simonsson S, Ronn T, Holmkvist J, Almgren P, et al. Genetic and epigenetic factors are associated with expression of respiratory chain component NDUFB6 in human skeletal muscle. J Clin Invest. 2007; 117(11):3427-35

36. Gong Y, Liu Y, Li J, Su L, Yu S, Zhu X, et al. Hypermethylation of Cox5a promoter is associated with mitochondrial dysfunction in skeletal muscle of high fat diet-induced insulin resistant rats. PLoS One. 2014;9(12):e113784.

37. Ronn T, Poulsen P, Hansson $O$, Holmkvist J, Almgren P, Nilsson P, et al. Age influences DNA methylation and gene expression of COX7A1 in human skeletal muscle. Diabetologia. 2008;51(7):1159-68.

38. Barres R, Kirchner H, Rasmussen M, Yan J, Kantor FR, Krook A, et al. Weight loss after gastric bypass surgery in human obesity remodels promoter methylation. Cell Rep. 2013;3(4):1020-7.

39. Barres R, Yan J, Egan B, Treebak JT, Rasmussen M, Fritz T, et al. Acute exercise remodels promoter methylation in human skeletal muscle. Cell Metab. 2012;15(3):405-11.

40. Nylander $V$, Ingerslev LR, Andersen E, Fabre O, Garde C, Rasmussen M, et al. lonizing radiation potentiates high-fat diet-induced insulin resistance and reprograms skeletal muscle and adipose progenitor cells. Diabetes. 2016; 65(12):3573-84.

41. Mudry JM, Lassiter DG, Nylen C, García-Calzon S, Naslund E, Krook A, et al. Insulin and glucose alter death-associated protein kinase 3 (DAPK3) DNA methylation in human skeletal muscle. Diabetes. 2017;66(3):651-62.

42. Jiang MH, Fei J, Lan MS, Lu ZP, Liu M, Fan WW, et al. Hypermethylation of hepatic Gck promoter in ageing rats contributes to diabetogenic potential. Diabetologia. 2008:51(8):1525-33.

43. Jiang M, Zhang Y, Liu M, Lan MS, Fei J, Fan W, et al. Hypermethylation of hepatic glucokinase and L-type pyruvate kinase promoters in high-fat dietinduced obese rats. Endocrinology. 2011;152(4):1284-9.

44. de la Garza AL, Etxeberria U, Palacios-Ortega S, Haslberger AG, Aumueller E, Milagro F, et al. Modulation of hyperglycemia and TNFalpha-mediated inflammation by helichrysum and grapefruit extracts in diabetic $\mathrm{db} / \mathrm{db}$ mice. Food Funct. 2014;5(9):2120-8.

45. García-Calzón S, Perfilyev A, Männistö V, de Mello VD, Nilsson E, Pihlajamäki J, et al. Diabetes medication associates with DNA methylation of metformin transporter genes in the human liver. Clin Epigenetics. 2017;9:102.
46. Martinez D, Pentinat T, Ribo S, Daviaud C, Bloks WW, Cebria J, et al. In utero undernutrition in male mice programs liver lipid metabolism in the secondgeneration offspring involving altered Lxra DNA methylation. Cell Metab. 2014;19(6):941-51.

47. Nilsson E, Matte A, Perfilyev A, de Mello VD, Kakela P, Pihlajamaki J, et al. Epigenetic alterations in human liver from subjects with type 2 diabetes in parallel with reduced folate levels. J Clin Endocrinol Metab. 2015;100(11): E1491-501.

48. Kirchner H, Sinha I, Gao H, Ruby MA, Schonke M, Lindvall JM, et al. Altered DNA methylation of glycolytic and lipogenic genes in liver from obese and type 2 diabetic patients. Mol Metab. 2016;5(3):171-83.

49. Nilsson E, Jansson PA, Perfilyev A, Volkov P, Pedersen M, Svensson MK, et al. Altered DNA methylation and differential expression of genes influencing metabolism and inflammation in adipose tissue from subjects with type 2 diabetes. Diabetes. 2014;63(9):2962-76.

50. Ronn T, Volkov P, Gillberg L, Kokosar M, Perfilyev A, Jacobsen AL, et al. Impact of age, BMI and HbA1c levels on the genome-wide DNA methylation and mRNA expression patterns in human adipose tissue and identification of epigenetic biomarkers in blood. Hum Mol Genet. 2015; 24(13):3792-813

51. Crujeiras AB, Diaz-Lagares A, Moreno-Navarrete JM, Sandoval J, Hervas D, Gomez A, et al. Genome-wide DNA methylation pattern in visceral adipose tissue differentiates insulin-resistant from insulin-sensitive obese subjects. Transl Res. 2016;178:13-24. e5

52. Cheng J, Song J, He X, Zhang M, Hu S, Zhang S, et al. Loss of Mbd2 protects mice against high-fat diet-induced obesity and insulin resistance by regulating the homeostasis of energy storage and expenditure. Diabetes. 2016:65(11):3384-95.

53. Gu T, Gu HF, Hilding A, Sjoholm LK, Ostenson CG, Ekstrom TJ, et al. Increased DNA methylation levels of the insulin-like growth factor binding protein 1 gene are associated with type 2 diabetes in Swedish men. Clin Epigenetics. 2013;5(1):21

54. Gu HF, Gu T, Hilding A, Zhu Y, Karvestedt L, Ostenson CG, et al. Evaluation of IGFBP-7 DNA methylation changes and serum protein variation in Swedish subjects with and without type 2 diabetes. Clin Epigenetics. 2013;5(1):20.

55. Toperoff G, Aran D, Kark JD, Rosenberg M, Dubnikov T, Nissan B, et al. Genome-wide survey reveals predisposing diabetes type 2-related DNA methylation variations in human peripheral blood. Hum Mol Genet. 2012; 21(2):371-83.

56. Simar D, Versteyhe S, Donkin I, Liu J, Hesson L, Nylander V, et al. DNA methylation is altered in B and NK lymphocytes in obese and type 2 diabetic human. Metabolism. 2014;63(9):1188-97.

57. del Rosario MC, Ossowski V, Knowler WC, Bogardus C, Baier LJ, Hanson RL. Potential epigenetic dysregulation of genes associated with MODY and type 2 diabetes in humans exposed to a diabetic intrauterine environment: an analysis of genome-wide DNA methylation. Metabolism. 2014;63(5):654-60.

58. Toperoff G, Kark JD, Aran D, Nassar H, Ahmad WA, Sinnreich R, et al, Premature aging of leukocyte DNA methylation is associated with type 2 diabetes prevalence. Clin Epigenetics. 2015;7:35.

59. Zhao J, Goldberg J, Bremner JD, Vaccarino V. Global DNA methylation is associated with insulin resistance: a monozygotic twin study. Diabetes. 2012;61(2):542-6.

60. Martin-Nunez GM, Rubio-Martin E, Cabrera-Mulero R, Rojo-Martinez G, Olveira G, Valdes $\mathrm{S}$, et al. Type 2 diabetes mellitus in relation to global LINE1 DNA methylation in peripheral blood: a cohort study. Epigenetics. 2014; $9(10): 1322-8$

61. Liu ZH, Chen LL, Deng XL, Song HJ, Liao YF, Zeng TS, et al. Methylation status of CpG sites in the MCP-1 promoter is correlated to serum MCP-1 in type 2 diabetes. J Endocrinol Investig. 2012;35(6):585-9.

62. Canivell S, Ruano EG, Siso-Almirall A, Siso-Almirall A, Kostov B, Gonzalez-de $P$, et al. Differential methylation of TCF7L2 promoter in peripheral blood DNA in newly diagnosed, drug-naive patients with type 2 diabetes. PLoS One. 2014;9(6):e99310

63. Chambers JC, Loh M, Lehne B, Drong A, Kriebel J, Motta V, et al. Epigenome-wide association of DNA methylation markers in peripheral blood from Indian Asians and Europeans with incident type 2 diabetes: a nested case-control study. Lancet Diabetes Endocrinol. 2015;3(7):526-34.

64. Dayeh T, Tuomi T, Almgren P, Perfilyev A, Jansson PA, de Mello VD, et al. DNA methylation of loci within ABCG1 and PHOSPHO1 in blood DNA is associated with future type 2 diabetes risk. Epigenetics. 2016; $11(7): 482-8$. 
65. Florath I, Butterbach K, Heiss J, Bewerunge-Hudler M, Zhang Y, Schottker B, et al. Type 2 diabetes and leucocyte DNA methylation: an epigenome-wide association study in over 1,500 older adults. Diabetologia. 2016;59(1):130-8.

66. Chen YT, Liao JW, Tsai YC, Tsai FJ. Inhibition of DNA methyltransferase 1 increases nuclear receptor subfamily 4 group a member 1 expression and decreases blood glucose in type 2 diabetes. Oncotarget. 2016;7(26):39162-70.

67. Horvath S, Zhang Y, Langfelder P, Kahn RS, Boks MP, van Eijk K, et al. Aging effects on DNA methylation modules in human brain and blood tissue. Genome Biol. 2012;13(10):R97.

68. Shaik MM, Gan SH, Kamal MA. Epigenomic approach in understanding Alzheimer's disease and type 2 diabetes mellitus. CNS Neurol Disord Drug Targets. 2014;13(2):283-9

69. Ficz G. New insights into mechanisms that regulate DNA methylation patterning. J Exp Biol. 2015;218:14-20

70. Day K, Waite LL, Thalacker-Mercer A, West A, Bamman MM, Brooks JD, et al. Differential DNA methylation with age displays both common and dynamic features across human tissues that are influenced by $\mathrm{CpG}$ landscape. Genome Biol. 2013;14(9):R102

71. Dick KJ, Nelson CP, Tsaprouni L, Sandling JK, Aïssi D, Wahl S, et al. DNA methylation and body-mass index: a genome-wide analysis. Lancet 2014; 383: (9933)1990-8.

72. Nitert MD, Dayeh T, Volkov P, Elgzyri T, Hall E, Nilsson E, et al. Impact of an exercise intervention on DNA methylation in skeletal muscle from firstdegree relatives of patients with type 2 diabetes. Diabetes. 2012;61(12): 3322-32.

73. Barres $\mathrm{R}$, Zierath $\mathrm{JR}$. The role of diet and exercise in the transgenerational epigenetic landscape of T2DM. Nat Rev Endocrinol. 2016;12(8):441-51.

74. Kwak SH, Park KS. Recent progress in genetic and epigenetic research on type 2 diabetes. Exp Mol Med. 2016;48:e220.

75. Flannick J, Florez JC. Type 2 diabetes: genetic data sharing to advance complex disease research. Nat Rev Genet. 2016;17(9):535-49.

\section{Ready to submit your research? Choose BMC and benefit from:}

- fast, convenient online submission

- thorough peer review by experienced researchers in your field

- rapid publication on acceptance

- support for research data, including large and complex data types

- gold Open Access which fosters wider collaboration and increased citations

- maximum visibility for your research: over $100 \mathrm{M}$ website views per year

At BMC, research is always in progress.

Learn more biomedcentral.com/submissions 